\title{
ENLOUQUECER O TEXTO DA LEI: \\ A VIOLÊNCIA DOS TRAÇOS AUTOBIOGRÁFICOS NA LITERATURA BRASILEIRA CONTEMPORÂNEA ${ }^{1}$
}

MADDENING THE TEXT OF THE LAW: THE VIOLENCE OF AUTOBIOGRAPHICAL FEATURES IN BRAZILIAN CONTEMPORARY LITERATURE

Milena Magalhães

Universidade Federal de Rondônia

Vilhena, Brasil

\section{Resumo}

A disseminação de traços autobiográficos na produção literária brasileira contemporânea, apesar de estudos recentes, reporta, ainda, uma série de questôes que dizem respeito, muitas vezes, ao modo genérico e homogêneo do tratamento dado ao tema. Investiga-se em que sentido o pensamento de Jacques Derrida, para quem a "tentação autobiográfica" sempre foi uma forma de contaminar a "língua" da filosofia, pode contribuir para responder ao que acontece e tem lugar no presente.

Palavras-chave: literatura brasileira contemporânea; autobiografia; Jacques Derrida.

\section{Abstract}

The sprinkling of autobiographical traces in the Brazilian contemporary literature production, despite recent publications, still reveals a set of questions that refer, in many cases, to the generic and homogeneous treatment dispensed to the issue. We enquire in which ways Jacques Derrida's thought, to whom the "autobiographical temptation" has always been a way to inoculate the "idiom" of philosophy, can contribute to answer to what happens and lives in the present time.

Keywords: Brazilian contemporary literature; autobiography; Jacques Derrida.

\section{Résumé}

Malgré les études récentes, la dissémination de traces autobiographiques dans la production littéraire brésilienne contemporaine renvoie encore à un ensemble de questions concernant, le plus souvent, la manière générique et homogène du traitement apporté au thème. On examine ici dans quelle mesure la pensée de Jacques Derrida, pour qui la «tentation autobiographique» a toujours été une manière de contaminer la «langue» de la philosophie, peut contribuer à répondre à ce qui se produit et se situe dans le présent.

Mots-clés: littérature brésilienne contemporaine; autobiographie; Jacques Derrida.

\footnotetext{
${ }^{1}$ Mais do que nos sentidos dados à palavra "violência" por Jacques Derrida, penso no sentido de "violência" a partir de um fragmento de Roland Barthes por Roland Barthes, em que se lê o seguinte: "Ele não conseguia sair dessa ideia sombria, de que a verdadeira violência é a do óbvio: o que é evidente é violento, mesmo se essa evidência é representada suavemente, liberalmente, democraticamente" (BARTHES, 2003: 99).
} 
Autorretrato

No papel fino do espaço

a minha figura pousa

seus traços e braços:

pedaços, quebra-cabeça

armando as suas peças

partes, pedras e passos:

a cada gesto o contato

tão tátil de fragmentos

(...)

(FREITAS FILHO, 2003: 221-222)

Um dos modos de dar forma à literatura brasileira contemporânea, de especificá-la, a partir de termos como "traços fortes", "linhas de força", ou para quem não teme correr o risco de estar fora de moda, "características gerais", é atribuir-lhe um sentido de aproximação com as potencialidades do uso e menção do "eu". Essa atribuiçãa, que jamais é inocente em sua potência de definir o que se passa no momento presente, carrega o problema, nem sempre contornável, do tratamento homogêneo que se costuma dar quando da imputação de determinado traço caracterizador de uma época, devido à dificuldade de tratamento caso a caso. A pulsão de arquivamento, com classificaçóes bem definidas, é uma maneira de compor a historiografia literária. Partir da exterioridade das classificaçóes, aludindo mais a aspectos gerais do que às demandas solicitadas a cada vez, é um gesto comum na composição dessa história.

Para tentar contornar esse problema, partirei de alguns poucos exemplos acerca das contendas que envolvem a presença de traços autobiográficos, especificamente, na prosa brasileira contemporânea, sem a ambição de analisar exaustivamente esses "casos", mas manter-se neles suficientemente para que possam dizer algo sobre a necessidade de questionamento a respeito do que acontece e tem lugar nos gêneros afins ao romance. Excluirei da análise a situação da poesia, visível apenas na epígrafe como indício de sua presença naquilo que será desenvolvido.

Nessa linha de força reconhecida, reiterada, alastrada nos estudos críticos contemporâneos, uma das aporias advém, justamente, do jogo com a ambiguidade do "eu". Os diversos possíveis lugares do "eu" em uma frase, narrativa, romance, enfim, num gênero artístico esfacelam, de imediato, qualquer coisa que sugira algo como pacto autobiográfico, demonstrando, de pronto, o anacronismo de tal proposta. A propensão está em forçar aberturas a partir do jogo com esse pronome pessoal, relacionado ou náo ao nome próprio que enfeixa um gênero como o romance, aberto a todo tipo de intervenção. 
Em uma nota de rodapé de Paixóes, Derrida credita a um dos "segredos" exemplares da literatura - o que consiste na possibilidade de tudo dizer e, ainda assim, manter o "segredo" intocável, manter a inviolabilidade do segredo - a indecidibilidade do lugar do "eu". É ele quem diz: "Ninguém poderá me contradizer seriamente se eu afirmar (ou subentender por elipse, sem tematizá-lo) que não escrevo um texto autobiográfico, mas um texto sobre a autobiografia, da qual este texto é um exemplo" (DERRIDA, 1995: 61). ${ }^{1} \mathrm{O}$ duplo gesto impóe um sem-fim de proposições, ao afirmar um traço potencialmente subversivo do gênero, no sentido de que um texto que demarca o autobiográfico é também um texto que inquire sobre as possibilidades e limites do autobiográfico. As marcas linguísticas e discursivas não servem para nenhuma delimitação inequívoca de um "eu", de "mim", o que é determinante para que a vizinhança com o gênero autobiográfico se estabeleça sempre de modo enviesado, passível de ser posta à prova. A indecidibilidade sobre quem fala ("eu") e de quem se fala (um "eu" que não "eu") pode ser mantida indefinidamente. ${ }^{2}$ Basta um movimento para que, no mesmo vocábulo, de maneira "econômica, elíptica e ironicamente", o rastro autobiográfico, em seu movimento próprio de presença-ausência, embaralhe as atribuições. Essa "frustração" (Derrida alude também à fruição e à interpretação sem fim), advinda do segredo da literatura, parece estar no cerne do desconforto ante críticas cuja tendência seja perscrutar o que é da ordem do arquivo do "real" e do arquivo da "ficção". Essa "tarefa impossível e sem-fim", nas palavras de Derrida, não pode sequer ser iniciada sem considerarmos o caráter ora especular, ora especulativo desse cruzamento de arquivos (DERRIDA, 2009).

Considerando-se, portanto, que, no interior da literatura, a expressão de um "eu" que se avizinha do nome próprio do autor realiza uma tarefa de "contaminação" dos gêneros, as discussôes não deveriam ser propriamente sobre o "eu", mas sobre o que este "eu" pode fazer no interior de um gênero para trasbordá-lo. Dito de outro modo, deve-se manter a desconfiança em relação a leituras imanentistas, que encontram nos jogos linguísticos todas as justificativas para o que acontece e tem lugar no texto, e também em relação às leituras biográficas e/ou sociológicas que, cruzando as relaçôes do dizer com os fatos da vida, julgam ser possível discernir os limites de um e de outra.

Assim, que sentidos podemos elaborar diante de um quadro de escritores que utilizam o "eu" - ainda que de maneira ambígua - a partir de um registro de indícios suficientes para relacioná-lo à figura do autor? Diana Klinger,

\footnotetext{
${ }^{1}$ Quando houver tradução dos textos de Derrida, salvo desconhecimento, farei uso da edição brasileira, indicando-a nas referências; caso contrário, as traduçóes são minhas.

${ }^{2}$ É, ainda, Derrida, nesta nota de rodapé, que reflete: "Falo de qualquer coisa ('eu') para dar um exemplo de qualquer coisa (um 'eu'), ou de alguém que fala de alguma coisa” (DERRIDA, 1995: 61).
} 
ao listar diversos escritores brasileiros que introduzem "componentes autobiográficos" em suas obras, instituindo, a seu ver, uma "presença problemática da primeira pessoa autobiográfica”, aponta o duplo lugar paradoxal em que parecem constituir-se: "estes textos parecem responder ao mesmo tempo e paradoxalmente ao narcisismo midiático e à crítica do sujeito" (KLINGER, 2012: 22). É uma hipótese bastante sólida, desde que discerníssemos o que seria "narcisismo midiático" e "crítica do sujeito" sem fazer uso da polarização, pois um leque de problemas se abre quando tentamos definir termos como "mídia", "narcisismo", "crítica", "sujeito" e suas relaçôes com o presente.

Derrida, ao designar dois traços que, para ele, constroem a atualidade em geral, utiliza-se de duas palavras-valises - artefatualidade e ato-virtualidade ao distinguir a atualidade do presente, produzindo um efeito de intempestividade que póe em destaque o fato de que a atualidade é "construida", "não é dada, mas ativamente produzida, crivada, investida, performativamente interpretada por um número de dispositivos falsos ou artificiais, hierarquizantes e seletivos, em geral a serviço de forças e de interesses que os 'sujeitos' e os agentes nunca percebem totalmente” (DERRIDA, 1996: 11, grifos do autor). Ora, sendo assim, a presença do escritor na mídia não necessariamente deve ser percebida como "narcisismo". Deve-se levar em conta que a ato-virtualidade, percebida como dispositivos constituídos num tempo e espaço virtuais que estruturam o acontecimento produzido, "dá lugar, sobretudo, a uma outra distribuição, a outros espaços, ritmos, reservas, formas de tomadas de posição e de intervenção pública" (DERRIDA, 1996: 14), de modo que não está totalmente interdita a negociação com esses dispositivos, estabelecendose relaçôes mais apropriadas ao trabalho de escritor. E isso sem se render à "cenografia", à montagem, escapando do modelo mediante uma experiência que aceite correr os riscos de dobrar a própria experiência de escrita, sem abrir mão da constituição de espaços aporéticos, nos quais não se aceita a solicitação de descobrir o véu dos impasses, das dificuldades, das impossibilidades, embora, seja preciso admiti-lo, não é o que comumente se observa. De todo modo, pode-se pensar, ainda com Derrida, na existência de um narcisismo mais e menos aberto à alteridade, à experiência do outro como outro.

Por isso, interessa-me menos classificar o que é feito hoje no Brasil em termos de gênero, como o faz Klinger ao elaborar novos parâmetros para o termo "autoficção", embora seja a partir de um trabalho como o seu que se tornam possíveis muitas das questóes aludidas aqui. Interessa-me, sobretudo, buscar compreender a clivagem dos discursos que deslizam na passagem do corpus e do corpo do escritor. Acredito que esta tem origem numa visão anacrônica, muito pouco conceitual, que não leva às últimas consequências as implicaçôes causadas pelo transtorno autobiográfico. Insisto nesse ponto por- 
que vejo nele a possibilidade de desconstruir alguns "nós" na produção literária recente, acrescentando dobras ao que nomeio, sem nenhuma intenção conceitual, de figura do "flagrante". Nos campos discursivos que estâo no entorno da constituição do nome próprio do escritor, é flagrante o descompasso entre a "performatividade literária" e a "performatividade crítica". Em linhas gerais, o gesto de discordância a que recorre parte dos escritores diante da menção de traços autobiográficos em suas obras deixa incompletos seus projetos literários, pois, em vez de estabelecerem o enfrentamento necessário à explicitação de suas razões - embora não necessitem coincidir com as razōes dos leitores e críticos -, tratam esses rastros como índices de "pobreza" a serem, senão descartados, continuamente rechaçados com o intuito de fazer sobressair ideais como "autonomia", "especificidade", "essência" da literatura, que estariam ameaçados caso não se anulasse a "limitrofia” entre arte e vida, pois é sempre em nome da ficção que os escritores em flagrante se declaram culpados, como se a literariedade fosse "uma essência natural, uma propriedade intrínseca do texto" (DERRIDA, 2009: 263). Discutem, portanto, a partir de parâmetros que pouco dizem respeito à contaminaçấo que enxertam em seus textos. Não é de se estranhar que também seja essa a visão expressa por parte da crítica, para a qual a proximidade com a experiência imediata é prova de incapacidade de transcendência.

2.

Uma frase de Ricardo Lísias, bastante vinculada à época do lançamento de seu romance Divórcio, diz muito sobre o que se passa na dita proliferação das "escritas de si": "Meu livro tem um ponto de partida pessoal e traumático e a partir dele criei um texto de ficção. A literatura não reproduz a realidade, mas sim cria outra". ${ }^{3}$ Embora seja impossível demarcar qualquer coisa que se assemelhe à origem, o "ponto de partida" aludido por Lísias é uma das faces mais visíveis e afeitas a críticas quando se trata de afirmar a porosidade de fronteiras causada pelos rastros autobiográficos na produção contemporânea. Esses lances autobiográficos, "pessoais", ora são verificáveis apenas no entorno das publicaçôes, com as máquinas de divulgação e recepção reconstituindo o drama da origem, ora performatizam sua presença no interior das obras, embaralhando acontecimentos como que diante de espelhos deformadores tanto do "real" quanto do "fictício".

\footnotetext{
${ }^{3}$ Pelo menos em dois jornais de prestígio esta frase serviu de parâmetro para os comentários. Na Folha de São Paulo (Disponível em: <http://www1.folha.uol.com.br/ilustrada/2013/08/1320746-pontode-partida-para-romance-divorcio-foi-pessoal-e-traumatico.shtml>), e em O Estadão (Disponível em: <http://cultura.estadao.com.br/noticias/geral,na-ficcao-as-estribeiras-perdidas-do-amor,1059991>).
} 
Em sua participação muito particular desse drama, como se fosse protagonista de um documentário monstruoso, ainda por existir, João Gilberto Noll faz coincidir, em Berkeley em Bellagio e Lorde - livros continuamente relacionados à contenda autobiográfica -, autor e narrador-personagem, delineando, no dizer de Marcio Renato, "diferenças e, até, incompatibilidades entre autobiografia e ficção", "tanto quanto (ou mais do que) indistinção" (PINHEIRO DA SILVA, 2009: 300). Temos, de um lado, o trabalho sob encomenda, derivado do financiamento de programas de residência, que envolve questóes de sobrevivência, comum na vida de escritores, mas quase sempre fora de cena; de outro, a remontagem da cena de origem para articular, ainda nas palavras de Marcio, "uma espécie de resistência à autobiografia" (PINHEIRO DA SILVA, 2009: 306, grifos do autor). Entretanto, apesar da formulação da "resistência", a proliferação de escritores, artistas, jornalistas, fotógrafos, professores universitários, como personagens colados aos seus criadores é vista, geralmente, como prova da falta de distanciamento, como se o intervalo para mediar as diferenças houvesse sido abolido. E isso porque essas figuras do comum estáo por demais próximas do nome próprio dos escritores. Daí, ser perfeitamente compreensível que seja aventada em tantos discursos críticos a possibilidade da autobiografia, ainda que seja uma outra que não a que se convencionou chamá-la como tal.

Tais enxertos monstruosos, incessantemente renegados, expropriados no momento mesmo de sua inserção, fazem com que um escritor como Michel Laub constantemente seja chamado a se explicar sobre a reinscrição de traços da experiência imediata em suas narrativas, resumindo-os, normalmente, a biografemas que comporiam ambientes, temporalidades, personagens sem recobrir os acontecimentos ficcionais, sem tocá-los de fato. Assim, o serviço militar, o estudo em escola judaica, a vida em Porto Alegre, a mudança para São Paulo estão e não estáo em seus textos, no sentido de que náo revelam a presença absoluta do que aconteceu. Ainda são "pontos de partida", embora a intenção seja deixar cada vez mais clara a complexidade de definir o que sejam "pontos de partida”, que terminam sendo, na cena geral do flagrante, apenas uma prova pouco convincente. E isso pode ser facilmente percebido em um livro como Diário da queda, de 2011, que se configura como um testemunho relativo ao Holocausto, que embaralha num grau maior, para além de biografemas, a história da família do autor. Pai, avô e o próprio narrador protagonista, um jornalista (como também o é Laub), estão bem próximos do arquivo do "real”, como um poderoso suplemento na participaçáo do "estive lá" da lei do testemunho.

Em outra ocasiáo, o escritor performatiza os espaços autobiográficos de maneira menos especular e mais especulativa, embora propor uma medição, uma distinção, seja uma forma de empobrecer a potência do duplo gesto. Em seu livro de 2009 (LAUB, 2009), um escritor de relativo sucesso e professor uni- 
versitário, após o rompimento traumático com a sua esposa, resolve contar em livro "tudo" que desencadeou os acontecimentos que levaram à separação. Há, na novela de Laub, uma nota de escândalo por causa do gesto do escritor. E os vários personagens envolvidos na trama têm a incumbência tanto de explicitar os acontecimentos eles mesmos quanto o de comentarem as consequências do que ali acontece. Assim, é sobre autobiografia a narrativa, em uma dobra reveladora.

Essa dobra, ao mesmo tempo especular e especulativa, de modos distintos, está presente em outros escritores. Livros de Silviano Santiago, como O grande mentiroso, Histórias mal contadas e mesmo Em liberdade, o qual joga abertamente com a relação que se estabelece entre o único e sua força de iterabilidade, encenam essa porosidade; são também tecidos que buscam compreender o esgarçamento do que se denomina fictício. E nos livros de Bernardo Carvalho, outro escritor em que se aponta comumente a indistinção entre o "real" e o "fictício", o "eu" somente aparece transversalmente, "fora do livro", como ocorre em Nove noites, com a foto, na orelha, que o mostra com os índios krahôs, geralmente lida como se fosse a chave dessa relação transversal. Florencia Garramuño suscita uma questão que espero desdobrar mais adiante: "A insistência no título do romance (Nove noites, dois-pontos, romance) aponta, talvez, para um gesto de apropriação, para uma redefinição contingente do literário..." (GARRAMUÑO, 2014: 38). Ou no interior do livro, como em As iniciais, em que a questão do nome próprio, por sua ausência, é tomada como fator de desestabilização, de modo que o romance, dividido em duas partes, que funcionam como espelhos deformadores, constitui-se como registro testemunhal para demarcar que não basta proferir o "eu", num registro confessional, para garantir a estabilidade do que aconteceu, uma vez que o "eu" que fala póe constantemente em jugo o que viu e vivenciou.

Com esse quadro ligeiro, de múltiplas entradas, longe de querer oferecer um panorama (diversos outros escritores poderiam ter sido incluídos), quis fazer ver que a “tentação autobiográfica” não possui um padrão definido, não produz modelos e exemplaridades nem mesmo quando se trata de relacionar os textos que compóem a obra de um escritor. Não é uma totalidade, tendo a aparência de formas anfíbias da presença diferida dos escritores. Nesse sentido, "as formas discursivas, os recursos de arquivação objetivante que temos à disposição são muito mais pobres do que o que acontece (ou deixa de acontecer), daí o excesso de hipertotalização" (DERRIDA, 2009: 255). Tem valor, portanto, a contrariedade, no sentido de que qualquer tentativa de identificação perturba a identidade.

3.

A hipertotalização talvez seja, então, o que mobilize escritores a responder por meio de gestos, muitas vezes, homogêneos, no que se refere à relati- 
vização dos traços autobiográficos, dificultando a demarcação das diferenças. Cristovão Tezza, Daniel Galera, Ricardo Lísias, Michel Laub e vários outros já se pronunciaram sobre a questáo. Em outra ocasião, caberia discutir o que diz cada um, mas num gesto derridiano, por falta de espaço, deter-me-ei um pouco mais no que afirma o último que, parece-me, opera uma pequena cisão nos discursos de outros escritores. A intenção é funcionar como uma espécie de acréscimo ao já-dito, para, após, confrontá-lo com outro discurso, mais afim ao que reiteradamente é dito nos lugares de fala dos autores.

Laub, na coluna quinzenal que mantém na Folha de São Paulo, ao tratar da "chamada autoficção, ou da tendência de escritores contemporâneos a usar elementos de aparência autobiográfica em suas obras” (LAUB, 2014), afirma que o debate lhe interessa "menos pelo que tem de estético do que por seus desdobramentos éticos”. É, portanto, uma (auto)crítica que escapa do caráter imanentista e aproxima-se do culturalista, em sua interrogação sobre os desdobramentos éticos do "espaço autobiográfico" no texto literário. Reivindicar seu nome próprio em outro espaço que náo seus livros, e do modo como o faz, é uma maneira de não ceder à facilidade da simples negativa: "Como escritor que já se baseou em fatos identificáveis por pessoas vivas - família, amigos de infância-, é inevitável me deparar com a pergunta”. O modo como enfrenta a "pergunta" é tanto uma esquiva, na falta de interesse pelo estético, que somente pode ser lida como denegação, quanto um enfrentamento, sobretudo devido à criação da metáfora nada lisonjeira que pode ser atribuída àqueles para a qual a esquiva consiste geralmente em reafirmar o fictício como forma de apagamento do autobiográfico. Essa abertura ao comentário acresce à sua obra uma dimensão mais íntegra, no sentido de manter uma correlação entre os gestos autorais. Não que Laub acredite no gesto sacrificial de ceder ao apelo fácil da autobiografia no seu sentido mais comum e, portanto, mais questionável, mas parece se interessar por entender as razóes de tantas esquivas referentes a um traço que é posto em cena justamente por eles mesmos - escritores:

Quem publica algo do gênero precisa assumir as consequências de suas escolhas. No caso do romance sobre o meu tio, dar entrevistas dizendo que o tema abordado é a medicina, a infância ou a questáo da segurança dos equipamentos náuticos no Brasil - o que poderá ser nas três hipóteses, sem tornar menos importante a pessoa real que usei para chamar a atenção - é querer ficar apenas com a parte boa da mamadeira.

Leitores nẫo sấo tấo manipuláveis assim. Achar o contrário é desconhecer a própria natureza humana. Uma ilusão, onipotência ou ingenuidade pouco lisonjeira para quem vive - justamente - de observar e retratar o comportamento dos homens (LAUB, 2014).

Ainda não é um enfrentamento das consequências para o texto dito literário contaminado pelo autobiográfico, mas a reflexão sobre a responsabilidade 
do escritor tem a vantagem de expandir as discussóes acerca da autonomia da literatura, levando a uma análise sobre a assinatura. Se a dinâmica da assinatura permite uma certa irresponsabilidade do escritor, ele deve contar, porém, que esta - a assinatura - não prescinde do outro para o qual a obra é destinada. Destacar a contra-assinatura, como o faz Laub, abre uma fresta para reconhecer que não é possível "manipular" aquele a quem o texto é destinado - não tanto, como sugere a resposta -, uma vez que ele participa do jogo proposto de distintas maneiras, inclusive abjurando o que se espera ser apenas reconhecido, no caso a assinatura. Em outras palavras, se num texto, obrigatoriamente, o "real" e o "fictício" não são mais que "indecidíveis", deve-se considerar que a perspectiva da interioridade e da exterioridade, para o leitor, sofre uma torçấo produzida tanto pelo texto quanto pelas virtualidades onde os escritores circulam. Se a destinação, na impossibilidade de ser controlada, é regulada por esses diversos dispositivos que buscam construir um leitor presumível, para assegurá -la é preciso mais do que simplesmente "querer ficar apenas com a parte boa da mamadeira”. Em Otobiographies, esse estranho texto em que trata de questóes da autobiografia, a partir do nome próprio, da assinatura de Nietzsche, Derrida lembra, ao tratar de um caso extremo como a suposta adesão de Nietzsche ao pensamento nazista, que "os efeitos e a estrutura de um texto náo se reduzem a sua 'verdade', ao querer-dizer de seu autor presumido, mesmo quando se trata de um signatário supostamente único e identificável” (DERRIDA, 1984: 93).

Pretende-se dizer, com tal citação, que está em jogo a integridade do corpus, que não continua o mesmo quando se enxerta nele algo estranho, algo inesperado, que irrompe como um acontecimento; é uma das hipóteses de Derrida, para quem a "biografia de um filósofo" não se presta apenas a uma leitura imanente, a única considerada legítima, uma vez que não existe um "fora" do sistema que seja totalmente mensurável. Um filósofo que ao proferir "eu", ainda que remarque que o faz para tratar sobre a autobiografia, e menos para fazer uma autobiografia, como diz ao diferenciar entre "dizer a verdade" e "fazer a verdade", discute as consequências do seu gesto para a filosofia, para o texto filosófico. É essa ausência de pensar as consequências para a literatura que, como sugeri, produzem projetos inacabados. O que Laub pressente, ao contrário, é de que há uma partilha entre quem assina e quem contra-assina. Segundo Derrida, "há como que um duelo de singularidades, um duelo de escrita e de leitura em que uma contra-assinatura pode tanto confirmar, repetir, respeitar a assinatura do outro, da obra dita original, quanto provocá-la, arriscando-se, assim, a traí-la” (DERRIDA, 2009: 287), sendo essa traição que, de certo modo, respeita a obra. Essa partilha, mais que duelo (é Derrida quem se corrige), advém do comprometimento, da "promessa de se comprometer", de quem assina. Se a "língua" da autobiografia irrompe na literatura 
e, como vimos, de maneiras distintas, essa "língua” também importa. É preciso, pois, comprometer-se com ela, num questionamento ininterrupto, corresponder à expectativa criada, não porque a obra esteja colada na pessoa civil que escreve. Pelo contrário, "certa irredutibilidade da obra" faz com que não seja possível pensar em seu porvir sem uma separação daquele que a assina. Esse ideário, bastante devedor do pensamento moderno, pode ser tratado nos termos das especificidades que cercam a publicação de livros com teor autobiográfico, cuja recepção é mediada pelo saber desse teor.

Nas palavras de Laub, no texto mencionado, tais livros "têm uma vantagem mercadológica frente a tantos outros que disputam os mesmos e escassos canais de divulgação e vendas. Afinal, estamos na era da narrativa confessional, do interesse mórbido na intimidade alheia”. Sem dados de mercado ou recursos para a análise criteriosa desta "era", que possibilitassem afirmar, relativizar ou negar essa opiniāo, gostaria apenas de ressaltar que essa particularidade raramente é mencionada pelos escritores, embora, quando há laivos do "real" em alguma obra, as editoras sejam as primeiras a alardeá-los; se crermos por um instante no que diz Laub, decerto para participarem de um filão mercadológico mais lucrativo do que a mera ficção. Dois casos recentes na produção literária brasileira especificam bem este movimento que, de um lado, prima pelo alardeamento e, de outro, pela denegação, senão pela relativização; de todo modo, sempre na forma de réplica. Trata-se dos romances $O$ filho eterno, de Cristovão Tezza, e Divórcio, de Ricardo Lísias; dois livros que tiveram repercussão imediata quando de seus lançamentos, com rápidas reedições e, no caso de Tezza, com o reconhecimento crítico advindo do recebimento dos prêmios mais prestigiados do setor. Nos dois, trata-se da indecidibilidade entre o gênero literário e o autobiográfico, produzida no corpo mesmo das obras, por meio de enxertos que indiciam a demarcação da origem, porém anunciam, em seu próprio formato (romance), a impossibilidade de demarcação.

Por já ter tratado do livro de Tezza em outro lugar (MAGALHÃES, 2012: 173-189), lançarei apenas alguns pontos relacionados ao romance de Lísias, exemplares do duplo movimento mencionado acima. Um texto publicado pelo escritor, em sua página de relacionamento, faz da frase "um livro de ficção, portanto", praticamente, um bordão, buscando esvaziar de imediato todo e qualquer contradiscurso que o relaciona ao espaço autobiográfico (que, digase de passagem, tem sido praticamente todos): "Há alguns meses publiquei o romance 'Divórcio' (um livro de ficção, portanto), inteiramente voltado ao meu projeto estético e que dava andamento a reflexóes que eu já vinha fazendo há algum tempo. Meu romance (um livro de ficção, portanto) tematiza em parte certos aspectos de certa imprensa brasileira” (LÍSIAS, 2013). Tal demarcação de lugar, se tem valor por sua ênfase, peca pela incapacidade de fazer o 
luto de sua própria perda identificatória, pois se se trata, ainda, de ficção é já uma outra que não se limita às suas leis de origem, visto que, em seu próprio escopo, rasura a ficcionalidade com diversas provas que depóem contra esta. Uma crise se instala, inevitavelmente, no que é tão facilmente nomeado de "ficção". Poder-se-ia perscrutar, se houvessem meios, por que se lê, agora, Divórcio? É provável que seja lido menos como um livro de ficção do que como uma autobiografia. É sempre possível reiterar o equívoco das leituras, apontando as diferenças com o autobiográfico propriamente dito. No entanto, diagnosticar uma crise no gênero autobiográfico como tal - e isso é feito desde que se constituíram as bases de sua definição - não é suficiente para que os traços que dizem respeito à vida, como "dados concretos e verificáveis", nas palavras de Laub, não tenham o potencial de rasurar o que seja "ficção", como se, em contato com esta, apenas o que diz respeito à vida sofresse alteraçóes, altercaçôes; apenas o gênero como tal da autobiografia deixasse de sê-lo.

$\mathrm{O}$ fato de não haver possibilidade de saber onde está o corte, ou mesmo se há, entre um discurso e outro, não deveria servir para a afirmação da generalidade da estrutura da ficção, pois é ao reconhecer os limites de um gênero que se pode alterá-lo, deformá-lo, para que ele continue subsistindo. Não é outra coisa que nos diz tantos discursos sobre a "morte" da arte, da literatura etc. A liçáo das vanguardas, no que havia nelas de mais interessante, parece não ter sido apreendida, pois havia, nelas a ousadia do jogo de enunciar o tipo de ruptura que se almejava. Não se tratando mais de ruptura, tratam do que exatamente esses textos que colocam em evidência o nome próprio, o corpo, a "letra", que facilmente podem ser relacionados à "figura real" do escritor? Se não há um dispositivo textual que valha a pena ser dissecado, para que realizá-lo? Por isso, não me parece razoável fazer uma defesa temática ("Meu romance... tematiza em parte certos aspectos de certa imprensa brasileira"), que, no cálculo geral da obra, é apenas um dentre os traços possíveis de demarcação, em detrimento do que, a meu ver, é bem mais elaborado. Essa ineficácia do discurso crítico para elaborar teses sobre a própria obra advém do apego ao princípio de identidade. Nesse gesto de negação, o escritor-crítico continua, assim, a falar de si mesmo e náo sobre o que fez em sua obra; sobre quais artifícios utilizou para promover o embaralhamento de que agora, fora do livro, precisa dar provas, até que haja a inevitável separação entre ambos.

Ir contra a "manipulação" do leitor - que quase sempre é um leitor do corpus do escritor, o qual abrange também os discursos críticos - passa também pelo questionamento das máscaras que pretendem funcionar como um "benefício de proteção", uma "mais-valia", do escritor, onde se reconhece facilmente a "dissimulação da vida" (DERRIDA, 1984: 45). Compreender o que tem lugar no presente talvez deva passar pelo gesto de dissecar as diversas más- 
caras, especulando os modos como alguns escritores póem em jogo o próprio corpo na constituição de seu corpus, como empenham o próprio nome na elaboraçẫo de suas ficçôes que, por isso, remetem à perda de sua especificidade.

Esse sentido é distinto da negação absoluta, engendrada nas autovirtualidades, pois a perda de identidade se dá a partir da concretização das "máscaras", como o faz Ricardo Lísias, em seu romance Divórcio, no qual a mesma nomeação para o que se convencionou ser visto como instâncias distintas do gênero romanesco acentua a indecidibilidade que atravessa o livro; indecidibilidade, como vimos, veemente e reiteradamente negada pelo autor ("um livro de ficção, portanto"). Retomamos a questão: se não for para manter o indecidível, qual a razão de o nome Ricardo Lísias ser ao mesmo tempo o do autor, narrador e protagonista de Divórcio? É possível ignorar que Lísias trata sua obra "com seu nome", "em seu nome"? (essas são expressóes sublinhadas por Derrida, ao referir-se a Nietzsche). Sáo ainda suas estas questóes: "Como não levar isso em conta quando se lê? Somente lemos para levar em conta" (DERRIDA, 1984: 43). Para esse filósofo, colocar em jogo a assinatura, de modo explícito, é encobrir tudo com uma "rubrica" autobiográfica que, presume-se, produzirá consequências. O nome próprio desdobrado, enxertado, em distintos lugares, será, portanto, assunto, tema, especulação. A constituição de uma "rubrica" autobiográfica que encubra a ficcionalidade de um texto é, antes de tudo, uma imagem poderosa, sobretudo, porque, ao anteceder o narrado, toma conta do narrado, aponta para o corte com "a lei do gênero".

No texto com esse título, Derrida marca a indecidibilidade intransponível que marca o relato ou a narrativa de Blanchot, La Folie du jour, que desde o título original, trazido à tona na leitura feita por ele, reduz a possibilidade de fechamento em um único gênero. (A primeira versão, na revista Empédocle, trazia na capa "Maurice Blanchot // Un récit?"; no sumário, o ponto de interrogação desaparece: "Maurice Blanchot // Un récit"; e, por fim, antes de começar, "Un récit / par / Maurice Blanchot"). As questóes endereçadas ao texto de Blanchot, ou a partir do texto de Blanchot, carregam uma espécie de luto à classificação dos gêneros. A "clausura" ou as "comportas" do gênero "dobram os sinos" de toda generalidade e de toda genealogia que constituem essa mesma lei do gênero. As comportas que represavam a lei se abrem dando lugar ao inclassificável, à hipótese de "uma lei de impureza" ou de "um princípio de contaminação" na lei instituída. Valendo-se do título de Blanchot, ele pode dizer que a lei "enlouquece" pelo "eu" inclassificável da narrativa ou do relato La Folie du jour. "A lei é uma loucura". "A lei é louca". E louca pelo "eu" (DERRIDA, 1986). Derrida faz uma espécie de "autorretrato do gênero", que lhe permite afirmar, em outro momento, que "uma teoria dos conjuntos do corpus deveria requerer o que poderíamos conside- 
rar como axiomas de incompletude" (DERRIDA, 2003: 84), e esses axiomas, tendo em vista que não basta uma menção ao gênero para este fazer parte do corpus, inibiriam a clausura da classificação.

Expandindo essa discussão, seguindo o "autorretrato do gênero", todo e qualquer texto gravitaria em torno da impossibilidade de estar restrito ao gênero que lhe é imposto. Essa "pertença sem pertença”, uma vez que não existiria texto sem gênero, evoca, novamente, o fato de essa discussão sobre o posicionamento crítico do escritor se justificar não porque ele gravita no exterior ou em torno de sua obra, mas, sim, porque situa-se "entre" o interior e o exterior, ou seja, há uma borda indiscernível entre o "dentro" e o "fora” indiscernível, no próprio corpo dos textos. Há, portanto, "contaminação", "impureza”, "hibridismo", se quisermos fazer uso de uma palavra mais comum ao vocabulário da produção contemporânea. Isso significa dizer que não é um movimento passivo nem pacífico, em que apenas o termo que contamina (no caso, a autobiografia) deixa de ser o que é, estando o outro termo (no caso, a ficção e, se quisermos, a literatura) imune ao ataque. Há restos. Nenhum corpus resta intacto. E se houvesse espaço, seria ainda possível dissertar sobre essa lógica do resto, que barra, por exemplo, a conclusão de Ricardo Lísias ("um livro de ficção, portanto”).

Escritores contemporâneos, em número suficiente para formar uma "comunidade", tratam ao mesmo tempo da literatura e da vida, inserem a vida em sua literatura, dispóem seus nomes e suas biografias a serviço de uma máquina geradora de opacidade, de inespecificidade, para fazer uso de expressões de Florencia Garramuño, no livro já mencionado; e essa partilha tem consequências. Como no poema de Armando Freitas Filho, o autorretrato é decomposto, mais do que composto; são traços de um possível quebra-cabeça que não possui mais que pedaços, fragmentos, que, entretanto, são táteis; é possível manuseá-los, inquiri-los, para o relance de outros gestos. E, de fato, é menos uma possibilidade e mais uma imposição; o leitor é requisitado a sondar o que o escritor está "armando", que, no caso desse poeta, e de outros, é o gesto mesmo de correr o risco de implicar seu nome num lugar (a literatura) de uma forma inesperada, ou seja, não mais apenas no exterior como prova de afirmação de autoridade, de autoria. Os traços autobiográficos na literatura brasileira contemporânea, que não se reduzem tão-somente aos modos aludidos aqui, transferem, na maioria das vezes, a centralidade do "auto" para a "grafia”, dando-lhes um aspecto problemático, mas são, ainda assim, gestos que devem ser avaliados a partir de suas ruínas, pois é das ruínas de um e outro gênero que se debatem tanto os escritores quanto os críticos. Deve-se acatar o risco constituído por esta chave de leitura não apenas para perscrutar o projeto literário de determinado escritor, mas para dar início a um diagnóstico sempre em suspenso da literatura brasileira contemporânea. 


\section{Referências bibliográficas}

BARTHES, Roland. Roland Barthes por Roland Barthes. Trad. L. Perrone-Moisés. São Paulo: Estação Liberdade, 2003.

DERRIDA, Jacques. "Cette étrange institution qu’on appelle la littérature”. In: DUTOIT, Thomas; ROMANSKI, Philippe. (Org.). Derrida d'ici, Derrida de là. Paris: Galilée, 2009. . Genèses, généalogies, genres et le génie. Les secrets de l'archive. Paris: Galilée, 2003. . Echographies de la télévision (entretiens avec Bernard Stiegler). Paris: Galilée, 1996. . Paixóes. Trad. L. Z. Machado. Campinas: Papirus, 1995. . "La loi du genre". In: . Parages. Paris: Galilée, 1986.

. Otobiographies. L'enseignement de Nietzsche et la politique du nom propre. Paris: Galilée, 1984.

FREITAS FILHO, Armando. "De corpo presente". In: Máquina de escrever: poesia reunida e revista. Rio de Janeiro: Nova Fronteira, 2003.

GARRAMUÑO, Florencia. Frutos estranhos: sobre a inespecificidade na estética contemporânea. Trad. C. Nougué. Rio de Janeiro: Rocco, 2014.

KLINGER, Diana. Escritas de si, escritas do outro: o retorno do autor e a virada etnográfica. Rio de Janeiro: 7Letras, 2012.

LAUB, Michel. "Autoficção e mamadeira”, Folha de São Paulo, São Paulo, 15 ago. 2014. Disponível em: <http://www1.folha.uol.com.br/colunas/ michellaub/2014/08/1500413-autoficcao-e-mamadeira.shtml>. Acesso em: 27 jan. 2015.

. Um gato diz adeus. São Paulo: Companhia das Letras, 2009.

LÍSIAS, Ricardo. "A biografia, a hipocrisia, a arte e o Chico Buarque”. 31 out. 2013. Facebook: Ricardo Lísias. Disponível em: <https:/www.facebook.com/rlisias/ posts/1429445893935359>. Acesso em: 27 jan. 2015.

MAGALHÂES, Milena. "As vidas paralelas de O filho eterno e do Espírito da prosa", Outra travessia, n. 14, 2012.

PINHEIRO DA SILVA, Marcio Renato. "Mímesis a contrapelo: ficção e autobiografia nos romances Berkeley em Bellagio e Lorde, de João Gilberto Noll”, Remate de Males, v. 29, n. 2, jul.-dez. 2009.

Milena Magalhães é professora de Literatura Brasileira na Universidade Federal de Rondônia e líder do GEPCEC - Grupo de Pesquisa em Poética Brasileira Contemporânea. Interessa-se pelas relaçóes entre literatura e autobiografia, literatura e regionalismo, literatura e ensino. Publicou, recentemente, os artigos "Uma biblioteca: leituras - A assinatura rasurada de Milton Hatoum" (revista Outra travessia); "As vidas paralelas de O filho eterno e de O espirito da prosa, de Cristovão Tezza" (Boletim de Pesquisa Nelic). Email: milena_guidio@yahoo.com.br 